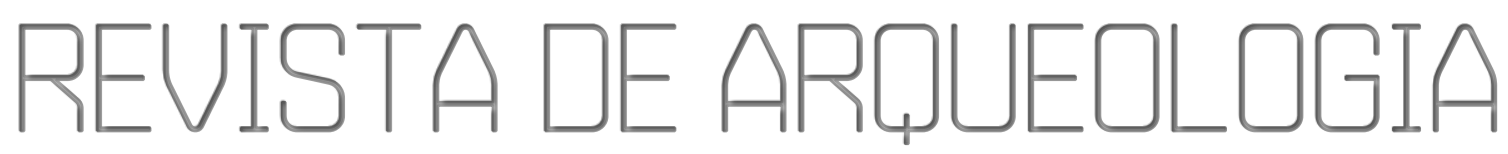

Volume 34 No.1 Janeiro-Abril 2021

FORMATION PROCESSES AND ANTHROPIC PROCESS IN THE ITAPEVA ROCK

SHELTER, SP - CONTRIBUTIONS FROM SOIL MICROMORPHOLOGY

Tatiane de Souza*, Vagner Carvalheiro Porto **

\title{
ABSTRACT
}

The study of soil micromorphology is a useful tool for detecting archaeological materials that archaeologists are unaware of in their excavations. The objective of this research is to present the results of Itapeva's rock shelter, located in the southwest of the State of São Paulo, Brazil. The results are derived from the production of thin sections that describe materials from two different areas of the site, called excavation units D18 and G6, referring to the north and south area and pointed to the existence of an anthropogenic soil with differentiation in its compositions. The conclusion is that the formed sediment is a mixture of sand, ash, wood and clay with long deposition periods derived from human occupation and natural deposition.

Keywords: soil micromorphology; formative processes, anthropic processes.

\footnotetext{
* Universidade de São Paulo, Instituto de Geociências, Departamento de Mineralogia e Geotectônica. E-mail: tatiane_sza@yahoo.com.br. ORCID: https://orcid.org/0000-0001-9285-4609.

** Universidade de São Paulo. Museu de Arqueologia e Etnologia. Departamento de Arqueologia.

E-mail: vagnerporto@usp.br. ORCID: https://orcid.org/0000-0001-6186-7845.
} 


\section{PROCESSOS DE FORMAÇÃO E PROCESSOS ANTRÓPICOS NO ABRIGO DE} ITAPEVA/SP - CONTRIBUIÇÕES DA MICROMORFOLOGIA DE SOLOS

\section{RESUMO}

O estudo da micromorfologia do solo é uma ferramenta útil para detectar materiais arqueológicos que os arqueólogos não conseguem avistar nas escavações. O objetivo deste artigo é revelar vestígios de ocupação humana a partir de uma análise micromorfológica. Os resultados são derivados da produção de seções delgadas que descrevem materiais de duas áreas diferentes do sitio, denominadas unidades de escavação D18 e G6, referentes às áreas norte e sul, e apontam para a existência de um solo antropogênico com formação de fogueiras. Conclui-se que o sedimento formado é uma mistura de areia, cinza, madeira e argila, que foi depositado em longos períodos e é derivado da ocupação humana e da deposição natural.

Palavras-chave: micromorfologia de solos; processos formativos; processos antrópicos.

\section{PROCESOS DE FORMACIÓN Y PROCESOS ANTRÓPICOS EN EL ABRIGO DE ITAPEVA, SP - CONTRIBUCIONES DE LA MICROMORFOLOGÍA DEL SUELO}

\section{RESUMEN}

El estudio de la micromorfología del suelo es una herramienta útil para detectar materiales arqueológicos que los arqueólogos desconocen en sus excavaciones. El objetivo de esta investigación es presentar los resultados del abrigo de Itapeva, ubicado en el suroeste del Estado de São Paulo, Brasil. Los resultados se derivan de la producción de láminas delgadas que describen materiales de dos áreas diferentes del sitio, denominadas unidades de excavación D18 y G6, haciendo referencia al norte y sur, y apuntan a la existencia de un suelo antrópico con diferentes composiciones. Se concluye que el sedimento formado es una mezcla de arena, ceniza, madera y arcilla con largos períodos de deposición derivados de la ocupación humana y la deposición natural.

Palabras clave: micromorfología del suelo; procesos formativos; procesos antrópicos. 


\section{INTRODUCTION}

The area in question covers the Umbu tradition refers to human groups that started occupying the south of Brazil 12,000 BP and seem to have maintained, for a long period, the same material characteristics (NOELLI, 1999/2000), such as the existence of projectile tips and wide constancy in the operational chain of production of this type of artifact repertoire, main item to distinguish them from other populations.

There are also dietary studies that show that, in the shelters of RS, there are small gastropods and also birds; mammals, such as armadillos and deer (JACOBUS; ROSA, 2013). In terms of habitat, this population would be assigned the occupation of shelters under a rock, with the presence of human burials. It also includes the Humaitá Tradition which in practical terms, there seems little to be distinguished from the Umbu Tradition regarding the making of an operational chain of artifacts, leading some researchers to question whether they are distinct Traditions (NOELLI, 1999/2000; HOELTZ, 2005). This distinction was defended by claiming that environments are occupied differently between one Tradition and another, the Umbu Tradition occupying the Hill, while the Humaitá Tradition would occupy the forest region (CHMYZ, 1967, 1968, 1977). It is also necessary to point out that some researchers consider it an error to associate ceramist periods based on an evolution of the Humaitá Tradition (NOELLI, 1999/2000; HOELTZ, 2005). This interpretation was assumed after analyzes carried out by researchers, who observed that in many sites with the presence of "boomerang" artifacts, distinctive of the Humaitá Tradition, technological processes similar to those produced by Umbu groups were presented. Finally, there is Itararé Tradition (Je Groups). It was defined as Itararé Tradition in the northeast of Paraná and southeast of São Paulo due to the form of spatial distribution that would occupy higher and colder regions.

The likely fact would be the presence of pottery, managed areas and seasonality of human occupation, allowing for subsistence based on the transition from hunting and gathering to agriculture (CHMYZ, 1968). Although ethnographers, historians and archaeologists (NOELLI, 1999/2000) suggest that these groups connects with colonial groups, it has not yet been a total disenchantment at which points pre-colonial and colonial groups would meet. The criticism towards this type of approach prevails on the classification of technological and decorative attributes of ceramic utensils and their current ethnographic relations, which would be precarious or distant in time.

It is necessary to define what is meant by Tradition, and contextualize its appearance to understand how the traces that take place in the Itapeva rock shelter were understood. The first generation of professionally trained archaeologists in Brazil retained French school precepts and, as a goal, to document stratigraphic sequences carefully, but on a small scale (BARRETO, 1998). Nevertheless, the North American influence was noticed during the 1960s and culminated in what was called Phase e Tradition, the regional distribution of human groups classified in cultural units was forged through fragile sampling and serialization based on few attributes (BARRETO, 1998). Furthermore, there was the need to present a brief synthesis of what could be representative of each Tradition, contextualizing current studies through fewer schematic approaches. In contrast to what has been put forward for the occupation of Jê, Tupi and Umbu groups regarding the spatial distribution of archaeological sites, these have undergone reassessments on a regional scale.

From the studies by Araújo, (2001) Tupi groups were expected to be in a topographical situation almost at the top of a hill (MORAIS, 1978). Nevertheless, in Itapeva, the Tupi sites are located in higher portions considered not normal for the implantation pattern in the middle Paranapanema valley. Of the Tupi sites registered in the area, 58\% were contained in higher altimetric levels (ARAUJO, 2001), revealing 
adaptations in the topography conditions of groups considered as Itararé. Although data on material culture for the area were produced according to the precepts of Tradition (ARAUJO, 2001; PERROTA, 2015), they present fewer schematic associations taking place. According to the prospected sites (ARAUJO, 2001) and analyzed site (PERROTTA, 2015) we have clues that the morphology, proximity and physical characteristics of ceramic objects from Tupi Tradition and Itararé are intertwined.

The descriptions point out that smooth and thin ceramic fragments of Itarare Tadition have "carena", or fragments of both Traditions are present in a single location. Another feature is the thick thickness of Itararé ceramics with white engobe (ARAUJO, 2001). For analyzed ceramic sites (Bianco) the technological description points to many unidentified fragments, thin thickness, antiplastic represented by quartz, hematite, coal and ground shards, the morphology of the extroverted edges and bases in flat form (PERROTTA, 2015). Because of these descriptions, a different situation is presented in this region, considering the stage of the protagonism of human groups in the process of diverse associations, according to a series of archaeological evidence: topography, material culture and form of occupation of archaeological sites.

No longer obtaining data on the material culture of the place, the strategy was to check the geographic coordinates and the distances established between sites according to information from the preventive archaeology registers, and to verify whether these were classified as belonging to an archaeological or other Tradition, according to the topography. The result indicates an important compartmentalization noted in the areas where these groups circulated.

The Itarare sites are located in the central zone, in immediate contact with Tupi groups in the north and Umbu groups in the south, but without direct contact with each other. In the south-central and southeastern portion there is the contact between Itararé and Umbu sites, which extends throughout the "Serra da Paranapiacaba" and a small area of the central portion, at the limit of the Taquari Guaçu River. An important observation is that Jê groups are nuclear occupying all areas and separating farming groups from hunter-gatherers, while the latter seem to meddle between Jê groups and acquire their spatialization habits. Therefore, it is difficult to agree on a distancing between different social groups in the area in question, being temporally more thoughtful to think of contacts that disseminate new habits in regions of internal micro borders, continually moving according to regional interests, dictated by measures that still need more studies. However, it is in accordance with what is found for the description of Jê groups in Robrahn (1989), where 60\% of the Itararé sites prospected by her and colleagues are in areas of the medium or high slope, or mountain ridges. (ALMEIDA et al., 2017).

It should also be remembered that, in general, the sites linked to the Umbu Tradition start to be located in the high and open portions of the plateau, close to the formations of gallery forest, 'araucarias" and fields, distributed along its southern border to the southwest and southeast (ROBRAHN, 1989). From this brief collection of data, soil micromorphology studies can be very useful to go beyond the analysis of the lithic and ceramic material culture, which itself is considered an artifactual analysis due to the anthropogenic origin of the soil, revealing deposition aspects intentional and management, contextualizing interpretations about the world view on the manipulated soil. This approach also allows archaeologists to unravel aspects of unintentional deposition and that the sum of these efforts may, in the future, be a measure of nonarchaeological features, caused by physical transport from diverse sources such as displacement by rain, wind, transposition watercourses or even by decomposition of the rock's physical structure. 
Figure 1 - Itapeva rock shelter according to location. By Carlos Rizzi (2020).

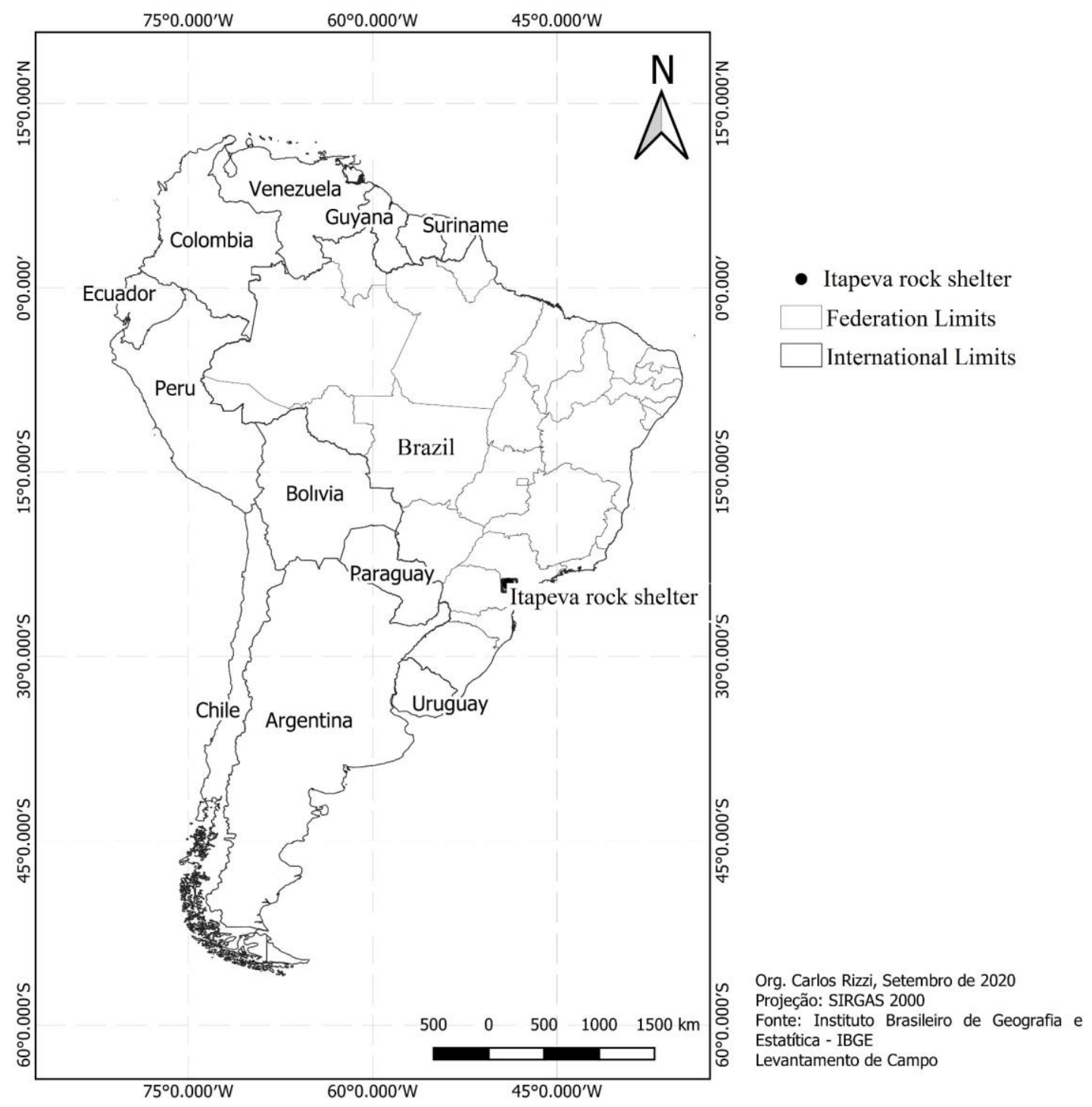

\section{RESEARCH AREA}

The high course of the Taquari River, a tributary of the Paranapanema River that originates in the foothills of Serra da Paranapiacaba, has been an object of archaeological interest since the late nineteenth century (ARARIPE, 1887). The Itapeva rock shelter is located in Itanguá canyon.

A canyon is characterized as steep-walled valleys. According to (GUERRA, 2004), this is a name related to deep and embedded valleys, which acquire typical characteristics when cutting sedimentary structures, forming a series of steps or plateaus along the corridor excavated by erosion. For decades, the typical relief of the Furnas Formation has suggested genesis based on dissolution phenomena, with the first existence of Devonian rocks in southern Brazil verified by Derbi (1878 apud MAACK, 1947). However, precisely from the 1940s, more systematic work began to be carried out in the region of Itapeva, through mapping at the service of the Geological Institute of the State of São Paulo and, during the 1960s, the diagenesis of these rocks is diagnosed (BERGAMASCHI, 1999). The Furnas Sandstone emerges in the canyon of the Taquari Guaçu river and this region, the escarpment of the Furnas Sandstone begins, of an 
extremely indented nature due to fluvial erosion, continuous and without interruption, which extends to the state of Paraná (PETRI; FULFARO, 1967).

The Itapeva rock shelter is located in the valley of the Taquari-Guaçu river, where it finds an escarpment to $20 \mathrm{~m}$ for height and around $20^{\circ}$ of the slope. Aytai (1970) interpreted the formation of the rock shelter as related to the detachment of part of the rock that spread at the top of the escarpment, resulting in the fall of a boulder based on 4 or 5 meters away from the wall. According to this author, the block and the wall that fell form a room of 4 to 7 meters of opening at both ends, almost totally free of vegetation and sheltered from the rain.

\section{ITAPEVA ROCK SHELTER}

The rock shelter excavation stages are available, to $1 \mathrm{~m}^{2}$ excavation units for stratigraphy and associated structures and artifact information on the site. The interventions aimed to obtain the refinement of the chronological and stratigraphic framework of this site justifying the investment in subsurface methods. In total, five field stages were carried out four concentrated in the shelter, for archaeological purposes; and one outside the rock shelter, to collect control samples that served the purpose of collating with the soil micromorphology produced inside it.

This site does not have a homogeneous base and the depth of the package on line 6y was tested, in a Dutch type auger until it reached a package with a greater thickness and was consistent with the location where it was different rock art stylistic motifs. Bearing in mind other structures of proven anthropic origin such as walls, walls and huts were not found, dealing with sediments and how it evolved along the excavation and in contact with material culture. Besides them, it was the sandstone blocks and the material apparatus of signs of burning that related everything was found inside the archaeological site. Then, a systematization of that was found in the excavation is carried out, according to artificial levels to $10 \mathrm{~cm}$ in units D18 and G6, according to the description of the sediment and indicative of anthropic action such as spots and non-spontaneous burning marks. Sediments will be highlighted in this work, due to the contribution of soil micromorphology and questions that directly link their anthropicity, the radiocarbon dating (table 1) and the structures found.

Table 1 - Age obtained by radiocarbon for the Itapeva rock shelter. Source: Beta Analytic inc. (2016). By Tatiane de Souza (2020).

\begin{tabular}{c|c|c|c|c|c}
\hline Sample & CRA & $\begin{array}{c}\text { Date cal } \\
(\mathrm{BP})\end{array}$ & Date cal (AD) & CI 95\% +- SE (BP) & CI 95\% +- SE (AD) \\
\hline Beta 432530 & $640+-30$ & 560 & 1.390 & $575 ; 540$ & $1.375 ; 1.410$ \\
\hline Beta 432531 & $860+-30$ & 730 & 1.220 & $770 ; 675$ & $1.180 ; 1.275$ \\
\hline Beta 432532 & $860+-30$ & 730 & 1.220 & $770 ; 675$ & $1.180 ; 1.275$ \\
\hline Beta 432533 & $1.470+-30$ & 1.310 & 640 & $1.365 ; 1.295$ & $585 ; 655$ \\
\hline Beta 432534 & $4.770+-30$ & 5.510 & 3.620 & $5.585 ; 5.505$ & $3.635 ; 3.555$ \\
\hline & & 5.560 & 3.610 & $5.585 ; 5.505$ & $3.635 ; 3.555$ \\
\hline
\end{tabular}

-CRA= Conventional Radiocarbon Age BP= Before 1950; AD= Anno Domini; $\mathrm{CI}=$ Confidence Interval; $\mathrm{SE}=$ Standard Error.

The absolute dates of the Itapeva rock shelter, collected in the excavation unit D18, indicate that up to $70 \mathrm{~cm}$ there is a relatively continuous occupation period, inserted in a homogeneous temporal spectrum. There follows a more distant period, allocated 
between $120 \mathrm{~cm}$ and $130 \mathrm{~cm}$, whose difference to $5 \mathrm{~cm}$ in the collection between one coal and another presents a substantial discrepancy in dating at the base level of the shelter. Soil micromorphology was able to contribute to the resolution of this time interval of distant dates. The oldest level is vestigial and close to bedrock, where there is almost no archaeological material. Just above, there are a lot of pottery fragments, flaked stone, human bones, fauna, seeds and charcoal. Human skeletal remains are found from a surface up to approximately $70 \mathrm{~cm}$ deep, associated with the latest radiocarbon information.

Figure 2 - Itapeva rock shelter. By Tatiane de Souza (2016).

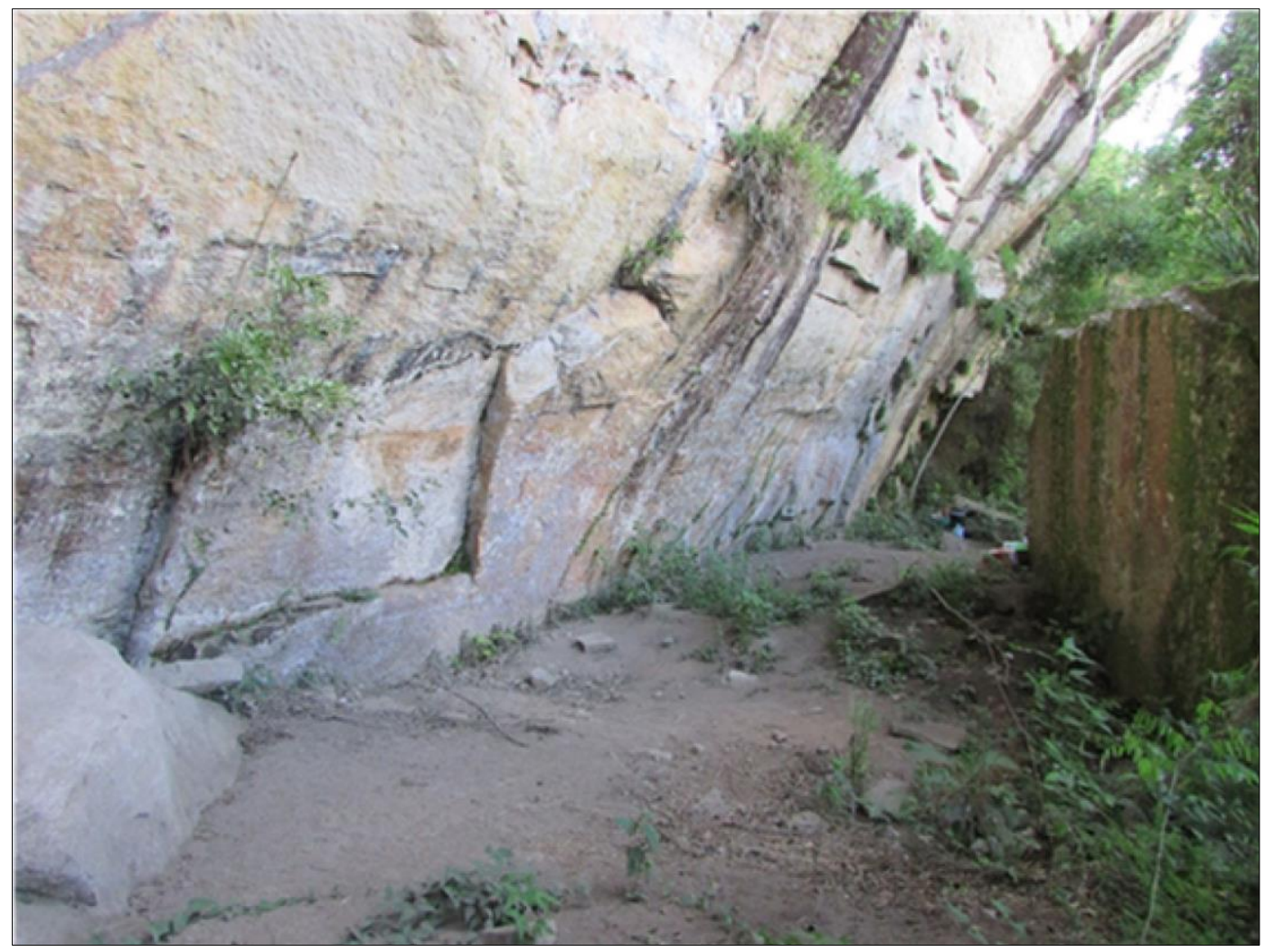

The processed data from the unit G6 show that from artificial level 1 to artificial level 3 there are moderate overlaps so that the fraction of fine gravel to very fine sand is predominant. At level 4/5, the overlapping sediments are inserted in the coarse sand fraction and cover the very fine gravel fractions to very fine sand. Level 6 has a different pattern so that there are discrepancies between layers that contain fine gravel to very fine sand and layers that contain very fine gravel to fine sand. At level 7, has the same pattern according to the distribution of level 6 . Level 8 has only very fine gravel to fine sand, while at level 9 the fractions are very fine gravel to very fine sand. At level 10, again the fractions are from very fine gravel to fine sand. At level 11 the fractions range from very fine gravel to fine sand, while at level 12 there are discrepancies between the layers, with fractions ranging from very fine gravel to fine sand and fine gravel to fine sand. The processed data from unit D18 show variations in the deposition pattern concerning to unit G6. Up to level 6, the fractions are very fine gravel to fine sand. From level 7, the fractions are very fine gravel to fine sand and fine gravel to very fine sand. At level 8 the same pattern is maintained, while at level 9 it repeats the formation of different fraction intervals. At level 10 and 11 there are fractions of fine gravel to fine sand while at levels 12 and 13 there are fractions of fine gravel to fine sand and fine gravel to very fine sand. 
It was possible to isolate this sedimentary deposition in some cases and demonstrate its evolution; however, it is also worth noting that they have their own characteristics that can be described as different deposition movements.

Selected granulometry is observed divided into granulometric fractions inserted in the coarse / medium to very fine sand fraction. In this way, it is possible to conclude, that the crude granulometric analyzes, together with the radiocarbon dating that the stratigraphy presents at least three intervals observed in macroscale; interval moments allocated in the coarse sand fraction and some points in the fine sand fraction, showing differences between the units in terms of deposition and the amount and type of particle involved each one. In the G6 unit there are several actions together, it is not possible to separate deposition levels absolutely. In unit D18, the intervals are clearer and delimited by specific fractions that can denote natural or anthropic selectivity.

The two excavation units behave differently from the base at level 7. Unit D18 appears to be related to a constant combustion area, while unit G6 is an area that has undergone a complex deposition process. Different behaviors do not necessarily mean the existence of different groups. However, the groups that inhabited the Itapeva rock shelter seem to have transferred the macro behavior that accompanies mound builders into the site. It is possible that hunter-gatherer groups occupied the area and amalgamated the habits of mound builders, or that otherwise, mound builders overlapped their habits with hunter-gatherer habits. The synthesis of the analysis indicates that hunter-gatherer groups were the first visitors, detected by the small amount of material culture and sediment change at the base. It is agreed that the site presents three moments of occupation, a quick one at the base, an intermediate period in which there are a series of interwoven cultural traits, whether through material culture and archaeological layers and a third moment from level 7. In unit D18 there is a change in the behavior pattern for excavation inside it, configuring itself as an exploited cavity, while in unit G6 there is an overlap of a set of layers that can be configured as a mound.

Table 2 - Compilation of sedimentary description, structures and human actions. By Tatiane de Souza (2020).

\begin{tabular}{cccc}
\hline$(\mathrm{cm})$ D18 & Facies & Munsell & Description \\
\hline 10 a 70 & 1 & 10 YR 3/3 & Dark spot in the center \\
\hline 70 & 1 e 5 & 7,5 YR 5/2 & little sticky sediment \\
\hline 90 & 1,5 e 6 & 7,5 YR 3/4 & little sticky sediment \\
\hline 100 & 1 e 6 & 10 YR 3/4 & Coal concentration \\
\hline 120 & 2 e 6 & 10 YR 3/4 & Burnt blocks \\
\hline 140 & 2 & 7,5 YR 5/8 & Sandy sediment \\
\hline$(\mathrm{cm})$ G6 & Facies & Munsell & Descriptions \\
\hline 10 a 20 & 1 & 10 YR 3/3 & Presence of litter \\
\hline 30 & 1,2 e 3 & 10 YR 4/4 & Coal concentration \\
\hline 40 & $2,3,4,5,6,7$ & 7,5 YR 3/2 & Sandy clayey sediment \\
\hline 50 & 2,6 e 7 & 7,5 YR 3/2 & Burnt earth concretions \\
\hline 60 a 70 & $2,6,8$ e 9 & 7,5 YR 5/1 & Burnt blocks \\
\hline 80 & $8,10,11$ & 7,5 YR 3/2 & Facies overlays \\
\hline 90 a 100 & 2 e 13 & 2,5 YR 2/2 & Slightly sticky sediment \\
\hline 110 & 13 e 14 & 2,5 YR 2/2 & Block in the center \\
\hline 120 & 13,14 e 15 & 7,5 YR 4/2 & Block in the center \\
\hline
\end{tabular}




\section{MATERIALS AND METHODS}

According to Marie Agnès Courty, soil micromorphology is not a new technique in the field of Earth Sciences, which includes disciplines such as Geology, Geomorphology and Pedology, however for years, within the archaeological discipline, it has been confined to the study of ceramics (COURTY et al., 1991, p. 5). Brewer (1964) was one of the precursors, by the study of Australian soils, although others point out that thin sections have been produced since the beginning of the 20th century (KUBIENA, 1938). In summary, soil micromorphology is just more than the study of physical and natural phenomena of soil formation, now also recognized as the traces associated with archaeological sites with lithic, ceramics and cooking signs (COURTY et al., 1991, p. 4). These traces are not immersed into the void, with sediments or soils around the material culture. This means reframing a very important concept for Archeology, or living floor. Therefore, five samples of the northern profile of the unit D18 excavation and six samples of the unit G6 were collected. It was processed in the Sedimentology Laboratory of the Institute of Institute of Geosciences of the University of São Paulo using oven drying for 48 hours at $40^{\circ} \mathrm{C}$ and the impregnation performed by Araldite Ciba Geybi Química SA, which presents a low toxicity and a lower concentration degree than the polyester resin. Subsequently it was impregnated the samples with the drip technique (FILIZONA; GOMES, 2004). After resin coated the samples were cut in the Institute of Geosciences of the University of São Paulo laminating section and examined in the polarized light microscopy field between the University of São Paulo and the University of Cambridge, United Kingdom. Several protocols using a scientific description of thin sections can be applied to archaeological soils. From Brewer (1964) with a review by (STOOPS, 2003) or most adapted to protocols of Brazilian soil analysis, mainly Castro (2008), there is the objective of describing the texture of the components and they become fundamental elements to distinguish geogenic processes of anthropogenic processes. It was observed from the divisions sectors, denominated A,B,C e D. All of the thin sections were examined at the microscopic of transmissive-reflexed light LEICA DM $750 \mathrm{P}$, at the University of São Paulo and LABORLUX Pol LEITZ in the Charles McBurney Laboratory for Geoarchaeology, at the University of Cambridge, United Kingdom.

The attributes of soil micromorphology analysis evaluated were:

- Grain size: division of grains into coarse, medium and fine sand (COURTY et al., 1991, p. 64);

- Selection: the level of uniformity (or variability) of different sizes compositions with relative percentage values (CASTRO, 2008);

- Variability: estimation of the abundance of a particular component or any group of components divided into nominal classifications (COURTY et al., 1991, p. 70);

- Shape and rounding: stipulated parameters for rounding the grains regarding the sharpness of corners and classification in: angular, subangular, sub-rounded, rounded, well rounded (CASTRO, 2008);

- Referenced guidance: considers the alignment of individuals according to the degree of guidance presented. The attributes are nominal: parallel, perpendicular, oblique, curved and unrelated (CASTRO, 2008, p. 57);

- Relative guidance: alignment of individuals in relation to other individuals. The attributes are nominal: parallel, perpendicular, oblique, curved and unrelated (CASTRO, 2008, p. 57);

- Pores or voids': the morphological classification, which Have nominal classifications: simple, cavities, vesicular, channels, alveoli (CASTRO, 2008). 
- Relative distribution: position of similar individuals in relation to different individuals and classified into:

a) Gerufic: finer materials that form bridges or arms between the coarse particles;

b) Chitonics: thinner materials, partially or entirely coated with coarse particles;

c) Enaulic: aggregates of finer materials, partially filled in the intergranular spaces between the coarse particles;

d) Porphyrical: the thicker particles will occur in matrix of finer material (COURTY, 1991; CASTRO, 2008).

\section{SOIL MICROMORPHOLOGY COLLECTIONS}

It is interesting to highlight the difference between horizon and layer, and whether it is the first or the second case. The excavation, carried out in different sectors according to the sampling method per one square meter, allowed to glimpse only layers and continuous/ discontinuous layers. This restriction did not allow observing the continuity of the layers on a large scale in the profiles. For the thin pedological sections, the objective was to delimit superficial diagnostic horizons, according to the 2015 technical manual of the Brazilian Agricultural Research Corporation (EMBRAPA, 2015), and to compare them with the thin archaeological sections.

Figure 3 - Sketches of collection of micromorphology of archaeological soils.

Soil Micromorphology collection in units D18 and G6. By Tatiane de Souza (2019).

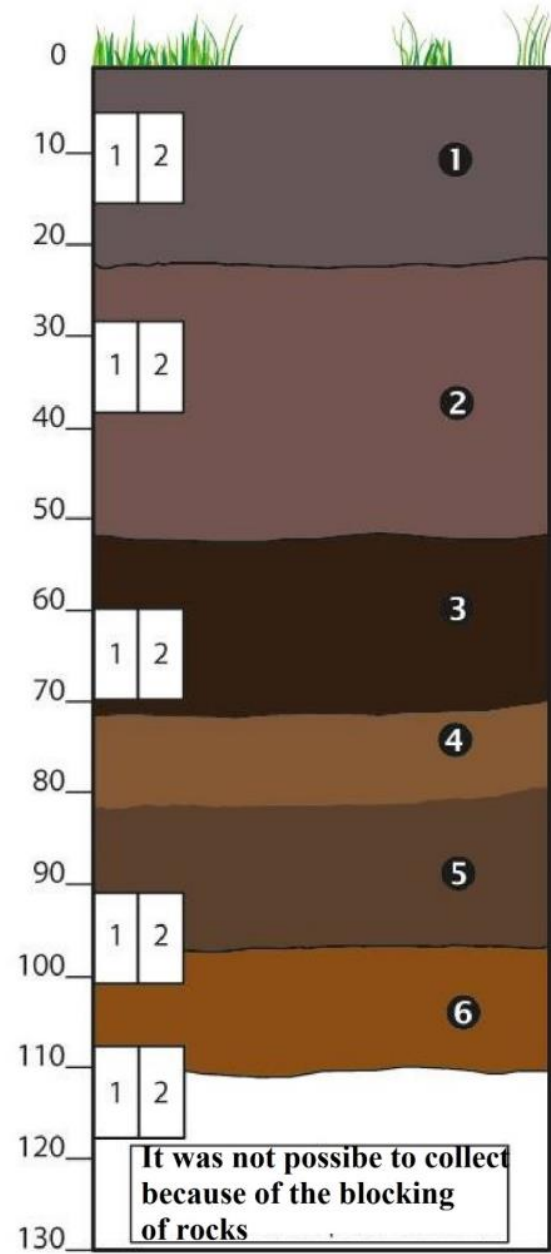

Escala 1:10

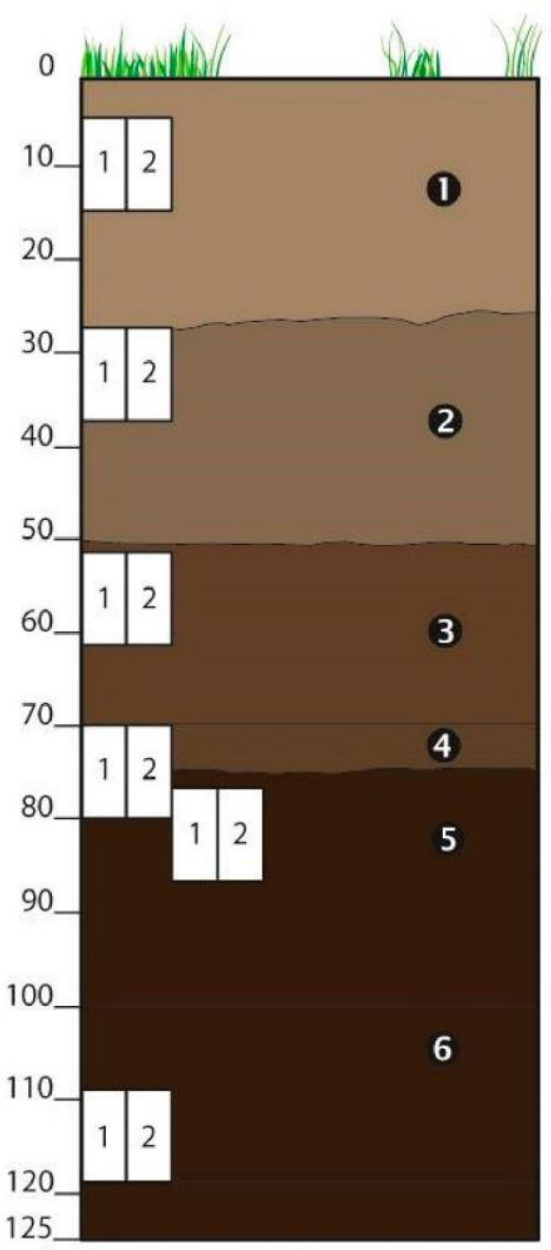

Escala 1:10 
D18 UN/T

1 - 10 YR 5/1 (dry), 10 YR 3/1 (wet).

Collect point: $5-15 \mathrm{~cm}$.

2- 10 YR 5/2, (dry), 10 YR 3/2 (wet).

Collect point: $27-33 \mathrm{~cm}$.

3 - 10 YR 5/5 (dry), 10 YR 3/2 (wet). Collect point: 59-69.

4 - 7,5 YR (dry), not collected.

5 - 10 YR 4/2 (dry), 10 YR 3/1 (wet).

Collect point: $91-101 \mathrm{~cm}$.

6 - 7,5 YR 5/5 (dry), 7,5 YR 5/6 (wet).

Collect point: $108-118 \mathrm{~cm}$.
G6 UNIT

1 - 10 YR 6/2 (dry), 10 YR 3/2 (wet).

Collect point: $6-16 \mathrm{~cm}$.

2 - 10 YR 5/2 (dry), 10 YR 3/2 (wet).

Collect point: $28-38 \mathrm{~cm}$.

3 - 10 YR 4/2 (dry), 10 YR 3/1 (wet).

Collect point: $52-62 \mathrm{~cm}$.

4 - 10 YR 4/2 (dry), 10 YR 3/1 (wet).

Collect point: $70-80 \mathrm{~cm}$.

5 - 10 YR 3/2 (dry), 10 YR 2/1 (wet).

Collect point: $77-87 \mathrm{~cm}$.

6 - 10 YR 3/2 (dry), 10 YR 2/2 (wet).

Collect point: $100-119 \mathrm{~cm}$.

\section{PEDOLOGICAL UNITS}

Figure 4 - Micromorphology sketches of pedological soils.

Control surveys 1 and 2 (Furnas Formation) and survey 3 (Itararé Formation).

By Tatiane de Souza (2019).

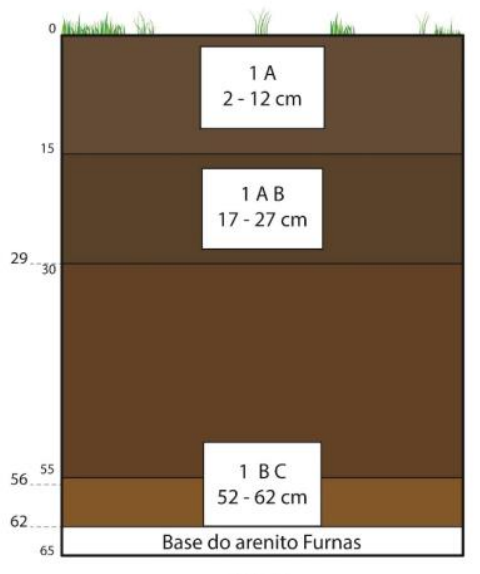

Escala 1:5

Survey 1

(Furnas Formation)

Horizon A: 10 YR 4/2 (dry). Collect point: $2-12 \mathrm{~cm}$.

Horizon A/B: 10 YR 4/3 (dry). Collect point: $17-27 \mathrm{~cm}$.

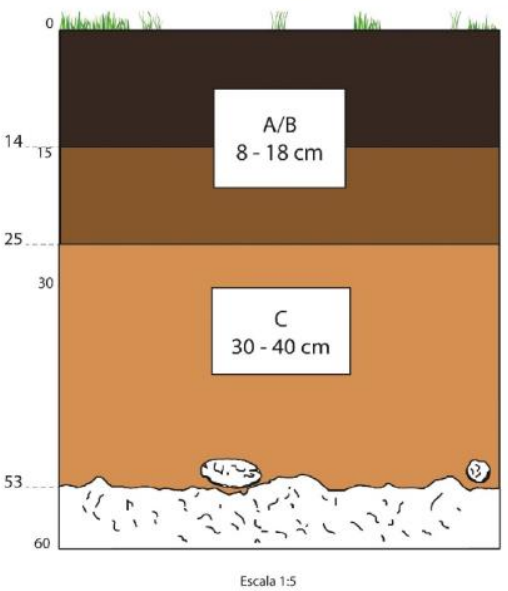

Survey 2

(Furnas Formation)

Horizon A/B: 10 YR 3/2 (dry). Collect point: $8-18 \mathrm{~cm}$.

Horizon C: 10 YR 7/6 (dry). Collect point: $30-40 \mathrm{~cm}$.

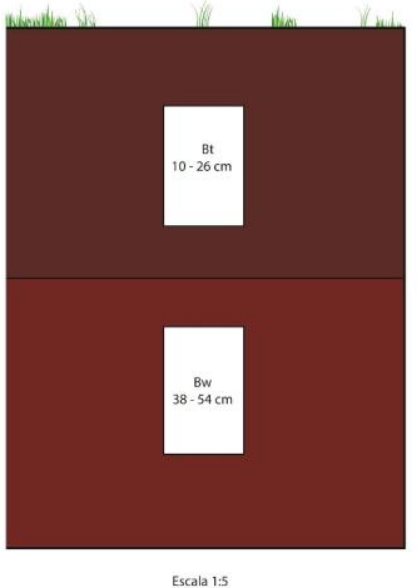

Survey 3

(Itarare Formation)

Horizon Bt: 2,5 YR 4/4 (dry). Collect point: $10-26 \mathrm{~cm}$.

Horizon Bw: 10 YR 4/8 (dry). Collect point: $38-54 \mathrm{~cm}$.

Horizon B 10 YR 4/4 (dry).

Collect point: $52-62 \mathrm{~cm}$. 


\section{RESULTS OBTAINED}

The analysis data extracted from thin sections soil micromorphology indicates that in the unit D18 excavation, at the base of the profile, there is a horizon with high porosity and low amount of charcoal films and iron oxide added to the grains of quartz. Charcoals and iron oxide are very minute and seems to participate just a little in this context being scarce; is observed above at $91-101 \mathrm{~cm}$ the grains are angular and sub-rounded prevailing the semi-clustered relative distribution, which may represent the beginning of processes of illuviation, transport or erosion or even processes of thermal heating caused by fires. In Unit D18, the presence of coals, ashes and breakdown oxides is patented, a mixture with ash formation in the central part and few preserved coals.

A halo of oxides forms around it, which can represent a combustion situation. Without a collection point $(59 \mathrm{~cm}-69 \mathrm{~cm})$, the presence of ash is intense and the quartz grains are well rounded, covered with fine material. Between 27 and $33 \mathrm{~cm}$, the surface of the grains is broken, and the number of rocks increases, such as flint, silicified sandstone and organic (bone). In the superficial layer, between 5 and $15 \mathrm{~cm}$, the film of clay and charcoal that surrounds the quartz grains are dissolving. In the G6 unit, at the deepest level $(100 \mathrm{~cm}-119 \mathrm{~cm})$, there is the capping of wrapping grains with coal and $\mathrm{Fe}$ oxide, point concentrations of cut coal and fine fractions in an area of marked porosity. The ashes are in this context. At the collection point $(77 \mathrm{~cm}-87 \mathrm{~cm})$ there seems to be more coal and less oxides in relation to the D18 unit. There are coals with radial fractures (trampling?).

The collection point $(70 \mathrm{~cm}-80 \mathrm{~cm})$ is composed of very fine particles, originating from the ash from combustion structures. Another type of information that refers to the burning product is the existence of phytoliths. According to sedimentary analyzes aimed at obtaining bioclasts, phytoliths were mostly classifiable (74\% to $86 \%$ ) and nonclassifiable (14\% to 26\%). Morphotypes show a predominance of Poaceae (grass) and Poaceae vegetation. , of the subfamily Pooidae (adapted to lower temperatures and / or altitude). The phytoliths characteristic of Arecaceae (palm trees) were also observed in relevant quantities. The collection point $(52 \mathrm{~cm}-62 \mathrm{~cm})$ are intermediate points of the excavation whose grains are capped without establishing points or connections of fine material between them and materials with selected and rounded grains, which may be a filling layer. At the point of collection $(28 \mathrm{~cm}-38 \mathrm{~cm})$, the presence of coal, which is ashes in disintegrating is noteworthy, and the grains are enveloped by oxides that are added to their surface.

One characteristic is the formation of clusters of coarse material, displaced from their original position. Finally, at the surface collection point $(6 \mathrm{~cm}-16 \mathrm{~cm})$ there is coal in disintegration in a state of ash, and heating characteristics that have already appeared in similar situations, suggesting the possibility on one level of combustion structure heating. The caption and the thin sections of figure 5 are shown below.

Figure 5 - 1 - Unit D18 - Presence of iron oxide or clay micromass B) angular quartz grains; C) Quartz grains rounded and wrapped with oxide; D) Fragmented quartz grains; E) Quartz grains with a very coarse fraction into smaller grains. 2 - Unit D18 - Phytolite (probable elongate morphotype); B) Coal; C) Fine matrix agglomerate; D) Channels with fine fraction; E) Whitish ashes; F) Phytolith (probably, elongate morphotype). 3 - Unit D18 - A) Warm and healthy bone coated with ash; B) Rounded quartz close to the bone; C) Undetermined cylindrical structure, likely phytolite; D) Microfilled quartz; E) Whole coals added to the bone. 4 - Unit G6 - Fragmented coal in geometric shape. 5 - Unit G6 - Fragmented coal, forming a system of channels with radial fractures. A likely trampling effect or combustion effect is perceived, as the ashes present themselves. 6 - Unit G6 - A) Coal in the process of transformation of ash; B) Quartz grains fraction well-rounded coarse sand; C) Diffused and blurred area surrounding the coal; D) Small cluster of rounded quartz grains, with oxide wrap. 
7 - Formation Furnas: Survey 1. 1, smaller quartz grains coming off larger grains; B) Quartz grains from where the smaller quartz particles are released, high level of porosity.

8 - Itararé Formation: angular quartz grains; from the morphoscopic point of view, the grains are corroded or angular minerals.

By Tatiane de Souza (2017).
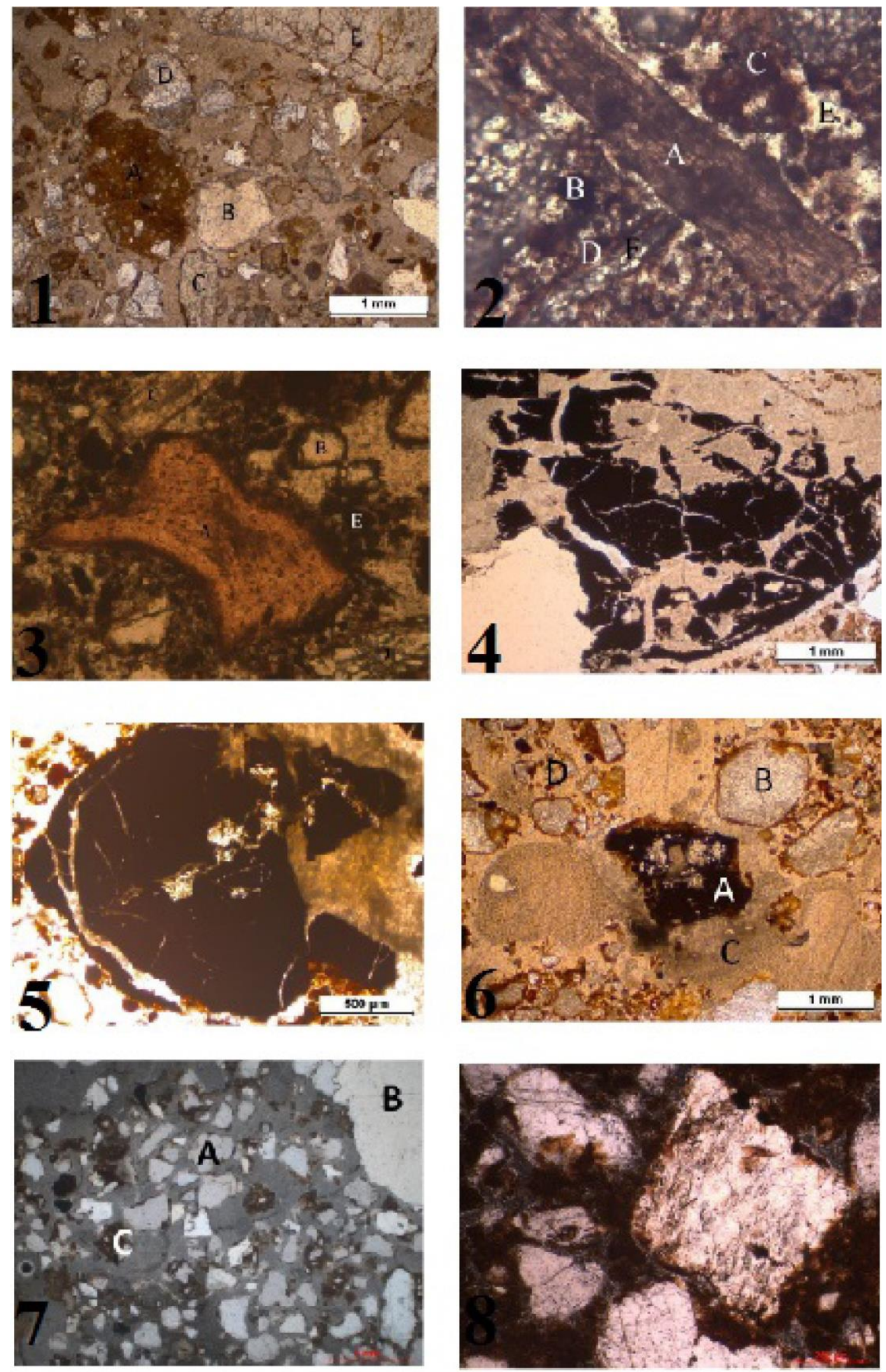


\section{DISCUSSION}

Soil micromorphology revealed that there is deposition of combustion structures. In fact, the unit D18 seems to have been chosen due to its natural characteristics that served as sediment traps that were gradually deposited inside, while the unit G6 presents different processes of combustion structures succession, taking advantage of natural aspects such as blocks suffering an accumulation of overlapping sedimentary layers. Respectively, there are combustion structures between $90 \mathrm{~cm}$ and $30 \mathrm{~cm}$ in both units. Included are waste and filling layers, prone to trampling, the presence of holes and specific traces of the site, resulting in combustion structures, coals and ashes.

In the unit D18, the soil has a dark spot in the center with a large amount of coal up to level 4. At level 5, the dark spot begins to lighten amid centimetric coals, with the presence of burnt sandstone blocks. At level 9, in addition to being characterized by loose, little sticky sediment, coarse, medium and fine sand fraction and centimeter fragments and silt, rounded and poorly selected grains, the color started to become gray after $5 \mathrm{~cm}$ excavation and it was removed a block of sandstone with burning marks.

In the unit G6, on level 3, a large amount of coal appears. At this level, very loose sediment and a large amount of dispersed coal are noted, without specific gray spots being noticed. At level 7 there is the appearance of a large sandstone block with a considerable amount of coal. This is a moment in which sequential overlaps prevail, and it may be a system of covering a structure that is below.

At level 10, a diffuse limit prevails between this level and those below it. At this moment, the excavation is obstructed due to the rectangular block and plane allocated in the central zone with patterns of rock selection such as size, thickness and positioning, which may be intentional object deposition. The exogenous and endogenous compositional characterization of the archaeological soil, mineral compositions and carbonate particles generated by the effects of ash deposition are added to the observation at different scales of analysis. From the ash deposited inside the soil and the sedimentary overlap and mixture in the unit G6 and the more compartmentalized granulometric intervals in the unit D18.

In the control surveys, they show a very different pattern of samples that contain very fine fractions and show that at the site is due to leaching or induced transport of alluvial sediments from the Taquari Guaçu river until the site. In this sense, these characteristics are interconnected with the geological characteristics of the area. Processes involving the Furnas Formation are considered formative in a very plastic environment.

The geomorphology of the area and the transport issues of clastic sediments occur in different ways. However, many of them come from rivers that run parallel to the research area, shed light on factors such as the formation of sediment banks, differential deposit process of sand and specific points of geomorphological cutouts. It can be argued that there is an open deposition system that encompasses anthropic sediments produced by burning and the possibility of transporting sediments just like transporting natural sediments either by wind, water, or the shelter's implosion or the anthropic characteristics such as burning.

\section{ACKNOWLEDGMENTS}

To Professor Francisco Sérgio Bernardes Ladeira of the Department of Geography at Unicamp, for his solicitude, availability and teaching of analysis of thin sections; and to FAPESP (proc. 2016 / 23584-6) and CNPq (proc. 408248 / 2016-5) projects filed by Professor Astolfo Gomes de Mello Araújo. 


\section{REFERÊNCIAS BIBLIOGRÁFICAS}

ALMEIDA, Fernando O.; MIGUEL, Rucirene; PEDOTT, Rafael; MONMA, Ricardo; BASSI; Fillipo S.; Amaral, Daniela M. Os ceramistas Jê nos arranha-céus do alto Ribeira: Uma análise espacial Itararé-Taquara. Cadernos do Leepaarq, v.14, n. 27, p.409-434, ja-jun, 2017.

ARAUJO, Astolfo. G. M. 2001. Teoria e método em arqueologia regional: um estudo de caso do alto Paranapanema, estado de São Paulo. (Doutorado em Arqueologia). Museu de Arqueologia e Etnologia. Universidade de São Paulo, São Paulo, 2001.

ARARIPE, Tristão. A. Cidades petrificadas e inscrições lapidares no Brazil. Revista do Instituto Histórico e Geográfico do Rio de Janeiro, T. 50, v.74, pt.1, p.213-294, 1887.

AYTAI, Desiderio. As gravações rupestres de Itapeva. Revista da Universidade Católica de Campinas, n.33, p.29-61,1972.

BALME, Jane; PATERSON, Alistair. Archaeology in practice. A student guide to archaeological analyses. ed. Malden, S/E. Blackwell Pub, 2006.

BARRETO, Cristiana. Brazilian archaeology from a Brazilian perspective. Antiquity, n.72: p. 573581, 1998.

BAR-YOSEF, Ofer; BELFER-COHEN, Anna. From Sedentary Hunter-Gatherers to Territorial Farmers in the Levant. In: GREEG, S.A (Ed.) Between Bands and States. Carbondale, Illinois: Southern Illinois University, Center for Archaeological Investigations, occasional Paper, 1991, p.81-202,

BAR YOSEF, Ofer. A personal view of earth science's contributions to archaeology. In: GOLDBERG, Paul; HOLLIDAY, Vance; FERRING, R (eds). Earth Sciences and Archaeology. New York: Kluwer Academic Plenum Publishers. 2001, p. 473-488.

BERGARMASCHI, Sergio. 1999. Análise do Siluro-Devoniano (Formação Furnas e Ponta-Grossa) da sub bacia de Apucarana, Bacia do Paraná, SP. (Doutorado em Geologia) Instituto de Geociências, Universidade de São Paulo, São Paulo,1999.

BERNA, Franscesco; BEHAR, Adir; SHAHACK-GROSS; BOARETTO, Elisabetta; GILBOA, Aylet.; SHARON, Ilan; SLAVEV, Sariel; SHIELTEN, Sana; MARK, Naama; ZORN, Jeffrey; WEINER, Steve. Sediments exposed to high temperatures: Reconstructing pyrotechnological processes in Late Bronze and Iron Age Strata at Tel Dor (Israel). Journal of Archaeological Science, n.34, p.358-373, 2007.

BITENCOURT, Ana Luisa Vietti. Morphogenèse, Quaternaire et Archéologie en Millieu Karstique: le site du Morro Furado, Serra do Ramalho (Bahia) - Brésil. (Doctorat en Geologie) - Université de Caen, Basse-Normandie, 1998.

BREWER, Roy. Fabric and Mineral Analysis of Soils. New York: John Wiley \& Sons, 1964.

BUTZER, Karl. W. Archaeology as human ecology: method and theory for a contextual approach. S/E, Cambridge, Cambridge University Press, 1982.

CANTI, Mathew G; Linford, Mary. The effects of fire on archaeological soils and sediments: Temperature and colour relationships. Proceedings of the prehistoric society, N.66, p.385-395, 2000.

CASTRO, Selma S. Micromorfologia de solos. Base para descrição de lâminas delgadas. $2^{\circ}$ edição. Campinas/Goiânia Unicamp IG, DGEO,UFG-IESA, 2008.

COURTY, Marie A; GOLDBERG, Paul; MACHPHAIL, Richard. Soils and Micromorphology in Archaeology. 2. ed. Cambridge: Cambridge University Press, 1991.

COURTY, Marie A. Microfacies analysis assisting archaeological stratigraphy. In: Goldberg, Paul; Holliday, Vance, T; Ferring, Reid (ed). Earth Sciences and Archaeology. New York: Kluwer Academic/Plenum Publishers, 2001. p. 205-293. 
CHMYZ, Igor. Pesquisas Paleoetnológicas Paleoetnográficas efetuadas no Vale do rio Paranapanema, Paraná e São Paulo. Boletim de Psicologia e Antropologia. n.5, p.01-248, 1977.

CHMYZ, Igor. Considerações sobre duas novas tradições ceramistas arqueológicas no Estado do Paraná. Pesquisas, Série Antropologia. São Leopoldo; Instituto Anchietano de Pesquisas, n. 18, p.115-125, 1968.

CHMYZ, Igor. O sítio arqueológico PR-UV-01 (Abrigo sob Rocha Casa de Pedra). Arqueologia. Revista do CEPA. Curitiba, UFPR, n.3, p. 1-140, 1967.

CHMYZ, Igor. Dados parciais sobre a arqueologia do Vale do Paranapanema, PRONAPA 1. Resultados preliminares do $1^{\circ}$ ano (1965-1966). Belém: Publicações Avulsas do Museu Paraense Emílio Goeldi, n. 6, p.59-78, 1967.

DeBLASIS, Paulo, Antonio. D. Resgate arqueológico no traçado Gasoduto Bolívia-Brasil (Gasbol) no estado de São Paulo: trechos IX e X (de Paulínia a fronteira com o Paraná. Relatório final, Universidade de Sao Paulo, 2000.

EIDT, Robert. C. Theoretical and practical considerations in the analysis of anthrosols. In: Rapp, George, Jr \& Gifford, John.A (eds). Archaeological Geology. S/E, New Haven, Yale University Press, 1985. p. 155-190.

EMBRAPA. Manuais técnicos em geociências. 3 ed, Rio de Janeiro, Manual técnico de pedologia, 2015.

FARRAND, William. R. Archaeological sediments in rockshelters and caves. In: STEIN, Julie; K; FARRAND, William. R. (Eds.). Sediments in Archaeological Context. Salt Lake City, UT: University of Utah Press, 2001, p. 29-66.

FOLK, Robert. L. Petrology of Sedimentary Rocks. 1 ed, Austin, TX: Hemphill Pub. Co. 1980.

FRENCH, Charles. Geoarcheology in action. Studies in soil micromorphology and landscape evolution. 1 ed, London and New York, Routledge. Taylor \& Francis Group, 2003.

FILIZOLA, Heloisa. F; GOMES, Marco A. F. Coleta e impregnação de amostra de solo para análise de micromorfologia. Comunicado técnico 20. Embrapa, 2004.

HOELTZ, Sirlei E. 2005. Tecnologia lítica: Uma proposta de leitura para a compreensão das indústrias do Rio Grande do Sul, Brasil, em tempos remotos. (Doutorado em Arqueologia) Universidade Pontifícia Católica do Rio Grande do Sul, Porto Alegre, Rio Grande do Sul, 2005.

GOLDBERG, Paul; MACPHAIL, Richard. Practical and theoretical geoarchaeology. S/E, VictoriaAustralia, Blackwell Publishing, Oxford, 2006.

GUERRA, Antônio T. Novo Dicionário Geológico e Geomorfológico. 4 ed, Rio de Janeiro, Bertrand Brasil, 2005.

JACOBUS, André L; ROSA, André. O. Os antigos habitantes do quadrante patrulhense e os animais. Pesquisas, Antropologia, n.70, p, 241-254, 2013.

KAMASE, Luciane M. Casas subterrâneas e feições doliniformes: um estudo de caso na bacia do alto Taquari (SP). (Dissertação de Mestrado), Museu de Arqueologia e Etnologia, Universidade de São Paulo, São Paulo, 2004.

KUBIENA, Walter L. Micropedology. 1 edition, Iowa, Collegiate Press, Ames, 1938.

LAMBERT, Joseph. B. Traces of the past. Unraveling the secrets of archaeology through chemistry. S/E, Massachusetts Helix Books, Addison-Wesley, Reading, 1997.

MAACK, Reinhard. Vestígios pré-devonianos de glaciação e a sequência de Camadas Devonianas no estado do Paraná. Curitiba: Instituto de Biologia e Pesquisas Tecnológicas. Breves notícias sôbre a geologia dos estados do Paraná e Santa Catarina. Arquivos de Biologia e Tecnologia. n.2, p. 66-154, 1947. 
MORAIS, José L. A ocupação do espaço em função das formas de relevo e o aproveitamento das reservas petrográficas por populações pré-históricas do Paranapanema, SP. São Paulo, Coleção Museu Paulista, Série Arqueologia, 1979.

MORAIS, José L. Inserção geomorfológica de sítios arqueológicos do Alto Paranapanema, SP. Revista do Museu Paulista. Nova série. São Paulo, n.25, p. 65-85,1978.

NOELLI, Franscisco S. A ocupação humana na região sul do Brasil: Arqueologia, debates e perspectivas. Revista USP, São Paulo, n.44, p. 218-269, (1999-2000).

PALlESTRINI, Luciana. Sítio Nunes. Estado de São Paulo. Projeto Paranapanema: Sítio Arqueológico Nunes, Estado de São Paulo. Revista do Museu Paulista, Nova Série. São Paulo, N.33, p.129-142, 1978.

PALLESTRINI, Luciana. O espaço habitacional em pré-história brasileira. Revista do Museu Paulista, Nova Série. São Paulo, n.25, p. 69-85, 1978.

PALLESTRINI, Luciana. Interpretação de estruturas arqueológicas em sítios do Estado de São Paulo. Revista do Museu Paulista, Série Arqueológica. São Paulo, n.1, p.1-208, 1975.

PALLESTRINI, Luciana. Sítio arqueológico Alves. Revista do Museu Paulista, Nova Série. São Paulo, n.21, p.47-94, 1974.

PALLESTRINI, Luciana. Sítio Arqueológico Fonseca. Revista do Museu Paulista; São Paulo, Universidade de São Paulo. 1969.

PALLESTRINI, Luciana. O sítio arqueológico "Jango Luís”. Revista do Museu Paulista, Nova Série. São Paulo, n.18, p.26-56, 1968.

PALLESTRINI, Luciana; CHIARA, Philomena. Indústria lítica de Camargo 76, município de Piraju, Estado de São Paulo. Coleção Museu Paulista, Série Ensaios. Coletâneas de Estudos em homenagem a Annete Laming-Emperaire. São Paulo, n.2, p. 83-122, 1978.

PALLESTRINI, Luciana; MORAIS, José L. Prassévichus: aldeia pré-histórica no município de Itaberá, SP. Revista do Museu Paulista, Nova Série. São Paulo, n.29, p. 151-167, (1983/84).

PALLESTRINI, Luciana; PERASSO, José G. A Arqueologia: Método y técnicas em superfícies amplias. Biblioteca Paraguaya de Antropologia, IV. Centro de Estudos Antropológicos, Universidade Católica, Asunción. 1984.

PERROTTA, Roberto M. 2015. Caracterização da Indústria Cerâmica do Sítio Bianco (Itapeva-SP). Possíveis Correlações Culturais. (Dissertação de Mestrado), Museu de Arqueologia e Etnologia, Universidade de São Paulo, São Paulo, 2015.

PETRI, Setembrino; FULFARO, Vicente. J. Considerações geológicas sobre a região de Itapeva, SP. Boletim da Sociedade Brasileira de Geologia. n.16, p. 25-40 1967.

PROUS, André. Premiére information sur les maisons souterraines de l'état de São Paulo. Revista de Pré-História, n.1, p.27-145, 1979.

ROBRAHN, Erika M. 1989. A ocupação pré-colonial do Vale do Ribeira de Iguape, SP: os grupos ceramistas do médio curso. (Dissertação de Mestrado), Faculdade de Filosofia, Letras e Ciências Humanas, Universidade de São Paulo, São Paulo, 1989.

STOOPS, Georges. Guideline for Analysis and Description of Soil and Regolith Thin Section. Editor America, Austin Soil Society of America, 2003.

STOOPS, Georges; MARCELINO, Vera; MEES, Flories. Interpretation of micromorphological features of soils and regoliths. S/E, Amsterdam, Boston, London, New York, Oxford, Paris, San Diego, San Francisco, Singapore Sydney, Tokyo, Elsevier. 2010.

WADLEY, Lyn. Cemented ash as receptacle or work surface for ochre powder production at Sibudu, South Africa, 58.000 years ago. Journal of Archaeological Science, n.37, p. 2397-2406, 2010. 